\title{
SEVERE ENDOTHELIAL DAMAGE IN CHRONIC KIDNEY DISEASE PATIENTS PRIOR TO HAEMODIALYSIS VASCULAR ACCESS SURGERY
}

\section{Vladimir Pushevski ${ }^{1}$, Petar Dejanov ${ }^{1}$, Vesna Gerasimovska ${ }^{1}$, Gordana Petrushevska ${ }^{2}$, Angel Oncevski ${ }^{3}$, Aleksandar Sikole ${ }^{1}$, Zivko Popov ${ }^{4}$, Ninoslav Ivanovski ${ }^{1}$}

${ }^{1}$ University Clinic of Nephrology, Skopje, R. Macedonia

${ }^{2}$ Institute of Pathology, Skopje, R. Macedonia

${ }^{3}$ University St. Cyril and Methodius, Skopje, R. Macedonia

${ }^{4}$ Macedonian Academy of Sciences and Arts, Skopje, R. Macedonia

Corresponding Author: Vladimir Pushevski, University Clinic of Nephrology, Medical Faculty Skopje, Vodnjanska 17; Tel: +389 (0)2 0727 75 46; E-mail:pushev@yahoo.com

\begin{abstract}
Background: Hemodialysis as an efficient therapy for advanced CKD is the most used treatment modality all over the world. Even though primary AVF is widely accepted as a best permanent vascular access in hemodialysis patients, up to $60 \%$ of all fistulas fail to mature. The pathogenesis of early fistula failure is not very well understood. Many general and local factors are involved: patient's age, sex, primary renal disease, small vessel's diameter, presence of accessory veins, prior venipunctures, surgical skill, genetics, etc. Histological investigations have confirmed the neointimal venous hyperplasia as a major pathological finding in stenotic lesions of AVF failure, due to local inflammation, oxidative stress and migration and proliferation of myofibroblasts, fibroblasts and endothelial cells.

Materials and methods: A total of 89 patients with stadium 4-5 of CKD are involved in the study. A typical radio-cephalic AVF is created in all patients. Part of the fistula vein was taken for histological, immunohistochemical (Vimentin, TGF $\beta$ and KI67) and morphometric analysis. Appriopriate statistical method was applied.

Results: Up to $80 \%$ of the patients showed some degree of endothelial changes at the time of creation of AVF, among them 19 pts with substantial intimal hyperplasia, 51 with medial hypertrophy and 19 pts with normal histology. Almost two thirds of the patients did not have expression of TGF $\beta$. More than 95\% had some expression of Vimentin. None of the patients had expression of the marker KI 67.

Conclusion: Medial hypertrophy is predominant preexisting pathohistological lesion prior the AVF creation, despite the presence of neointimal hyperplasia. The absence of TGF $\beta$ expression in majority of our patients could suggest that inflammation and oxidative stress are developing later, after vascular access surgery. The dominant cells within the stenosis in the veins are myofibroblasts. Their increased presence maybe a reason why some patients are prone to developing venous endothelial changes as a results of exaggerated vascular endothelial response to the effect of uremia, hypertension and other insults.
\end{abstract}

Keywords: Fistula Failure, CKD, Intimal Hyperplasia, Vimentin, TGF- $\beta$

\section{Introduction}

Hemodialysis as an efficient therapy for advanced CKD is the most used treatment mo- dality all over the world [1-3]. Approximately about 3 million people are on regular dialysis program, predominantly using arterio-venous 
fistula (AVF) as a permanent vascular access. On the other hand, the problems associated with vascular access dysfunction are the most common reason for increased morbidity, mortality and hospital admittance and represent major clinical, social and financial burden even for the developed countries. Even though primary AVF is widely accepted as the best permanent vascular access in hemodialysis patients, up to $60 \%$ of all fistulas fail to mature [4-6]. The pathogenesis of fistula failure is not very well understood. Many general and local factors are involved: patient's age, sex, primary renal disease, small vessel's diameter, presence of accessory veins, prior venipunctures, surgical skill, genetics, etc [7-10].

Neointimal hyperplasia is the dominant histological finding that leads to significant stenotic lesions and ultimately AVF failure. There is not enough data about the cellular phenotype and possible future impact of preexisting CKD related factors on AVF failure. Oxidative stress, inflammation and low shear stress are well known factors which contribute to neointimal hyperplasia.

The aim of the study is to perform histological, morphometric and immunohistochemical examination of vein samples from CKD patients collected at the time of vascular access creation.

\section{Material and methods}

\section{Study populations}

A total of 89 patients with stadium 4-5 of CKD are involved in the study. A typical radiocephalic AVF is created in all patients. The standard preoperative assessment of both extremities was performed, including physical examinations and ultrasound Doppler mapping for evaluation of vein and artery diameters. Demographic data were obtained in the time of patients' referral.

\section{Specimen collection and processing}

During the operative procedure an 8-10 $\mathrm{mm}$ of circumferential segment of the vein was removed near the anastomosis site. The specimen was fixed immediately in the buffered formalin and sent to the pathologist. Each tissue sample was embedded and cut into three or four blocks of 2-3 $\mathrm{mm}$ using previously described technique. After embedment in paraffin, each piece was sliced in sections of 4 micrometers for histological and immunohistochemical analysis. The samples were evaluated with hematoxylin and eosin (H\&E) and van Gieson (vG) stain for usual histological analysis and Vimentin (marker for fibroblast), TGF $\beta$ (marker for inflammation and oxidative stress) and KI67 (marker for cellular proliferation) for immunohistochemistry. A semiquantitative scoring from 0-4+ was used for the assessment of the intensity of the positive cells for the above mentioned markers in different parts of the venous wall $(0$ represents $0-10 \%$ positive cells, $1+=$ $11-25 \%, 2+=26-50 \%, 3+=51-75 \%$ and $4+$ $=76=100 \%)$.

\section{Morphometric analysis}

Image $\mathbf{J}$ software (National Institutes of Health) was used for morphometric analyses. Values for luminal area (L,), intimal area (I,), medial area (M,), percentage of luminal stenosis, Intimal-medial area ratio, average and maximal intimal-medial thickness were obtained from vein samples from each individual patient. The luminal area (L) was measured by tracing around the edge of the lumen. The intimal area (I) was measured by tracing around the internal elastic lamina, then subtracting the luminal area. The medial area (M) was measured by tracing around the external elastic lamina, then subtracting the intimal area. Intimal-medial area ratio was calculated by the formula (I-M)/(L/I). The percentage of the luminal stenosis was calculated using the formula $[1-\mathrm{L} / \mathrm{I}] \times 100$. The average intimal-medial thickness (It-Mt) was obtained by averaging the measurements between the tracings used for separating both layers. The ratio of the average intimal to medial thickness was calculated by the formula It/Mt. Finally, one measurement was done from the point of the maximal intimal thickness, and then the maximal intimal-medial thickness was measured in the same way (MaxIt/Mt). By comparing the average and maximal intimal-medial thickness we can assess the eccentricity of the neointimal distribution. 


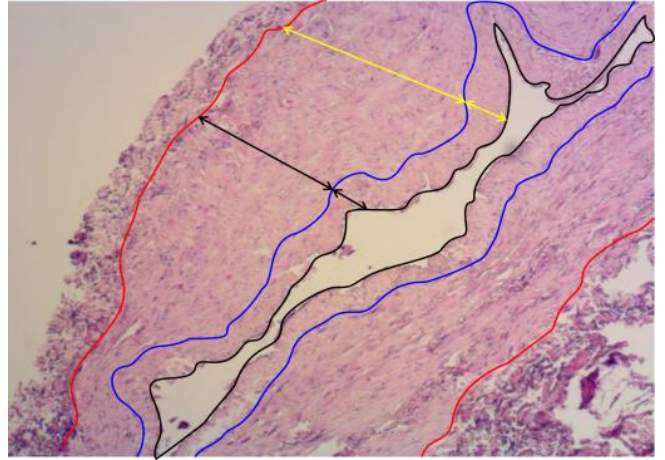

Figure 1-Morphometric analysis. The lumen is circled with black line, the intima with blue and the media with red line. The black double arrows show intimal thickness (It) and medial thickness (Mt). The yellow double arrows show the maximal Intimal (MaxIt) and maximal medial thickness (MaxMt)

\section{Statistics}

The distribution of the variables was evaluated according to the means+ SEs, medians and proportions. Associations between quantitative expression of different markers and early fistula failure were analyzed using univariable logistic regression. All statistical analysis was performed using the SPSS software package.

\section{Results}

\section{Demographics}

Eighty-nine CKD patients (50 men and 39 women) were enrolled in the prospective, open, observational study. The median age was $62 \pm 13$ years (range 16-86). The underlying diseases were: Diabetes 20, Hypertensive Nephropathy 30, End Stage Renal Disease 18, Nephrolithiasis 7, Glomerulopathies 6, Adult Polycystic Kidney Disease 3, Pyelonephritis 2, Vesicoureteral Reflux 2, Vasculitis 1. All AVFs were preemptive and first vascular access.

Histomorphometric analysis

All 89 patients had adequate tissue samples for histological analysis. A substantial venous luminal stenosis $(71.45 \pm 23.7 \%)$ was found in most of the patients (Figure 2,3) on $\mathrm{H} \& \mathrm{E}$ and $\mathrm{vG}$ staining. Up to $80 \%$ of patients showed some degree of endothelial changes at the time of creation of the AVF, among them 19 pts with substantial intimal hyperplasia, 51 with medial hypertrophy and 19 pts with normal histology. The histomorphometric analyses are presented on Table 1. The values for intimal-medial area ratio and average intimial-medial thickness confirm the significant role of the medial hypertrophy in the stenotic lesions as oppose to intimal hyperplasia. The significant difference between the maximal versus the average intimal - medial thickness suggests that the intimal lesions are eccentric (Fig. 2)

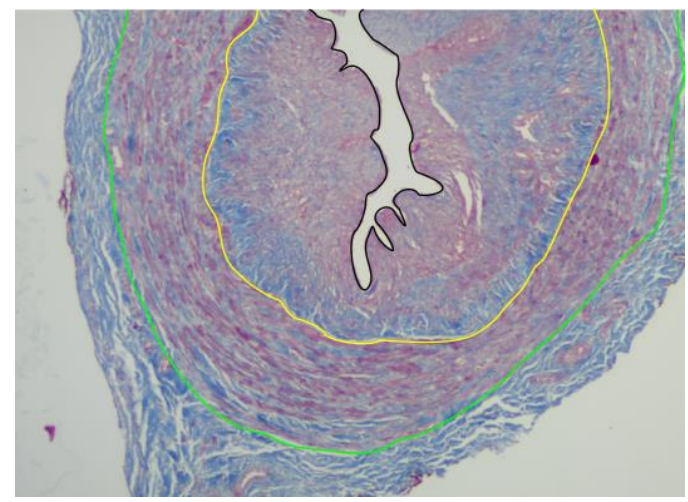

Figure 2 - Neointimal hyperplasia prior AVF creation. The lumen is circled with black line. The intima with yellow and the media with green line

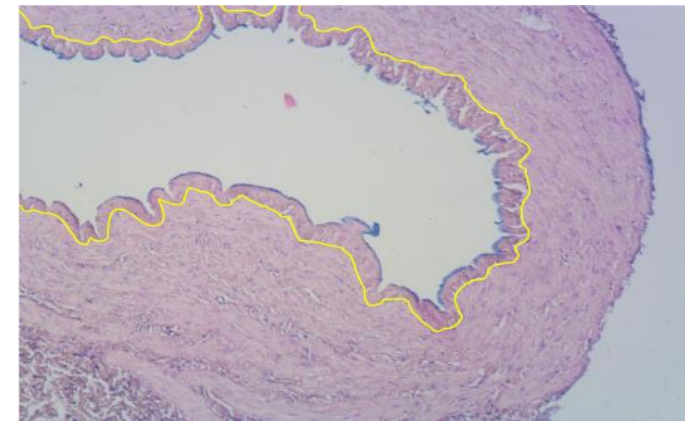

Figure 3 - Predominant medial hypertrophy prior AVF creation. Intimal hyperplasia can be seen

Table 1

Mean values for vein samples before AVF creation

\begin{tabular}{|l|l|l|l|}
\hline Stenosis (\%) & Intimal-medial area ratio & $\begin{array}{l}\text { Average intimal-medial } \\
\text { thickness }\end{array}$ & $\begin{array}{l}\text { Maximal intimal-medial } \\
\text { thickness }\end{array}$ \\
\hline $71.45 \pm 23.7$ & $0.09 \pm 0.5$ & $0.19 \pm 0.2$ & $0.44 \pm 0.3$ \\
\hline
\end{tabular}


Immunohistochemistry

A standard immunohistochemical analysis for the markers TGF $\beta$, Vimentin and KI67 was done from the samples taken at the time of AVF creation. The results from the semiquantitative scores are presented on Table 2 and 3. We did not find any positive stains for the marker Ki67. The results for TGF $\beta$ and Vimentin are also presented on Fig 4 and 5.
Table 2

TGF-semiquantitative score

\begin{tabular}{lc}
\hline TGF- semiquantitative score & All \\
\hline $0 . \quad 0-10 \%$ positive cells & $55(61.79 \%)$ \\
1+. 11-25\% positive cells & $16(17.98 \%)$ \\
2+. 26-50\% positive cells & $15(16.85 \%)$ \\
3+. 51-75\% positive cells & $3(3.37 \%)$ \\
Total & $89(100 \%)$ \\
\hline
\end{tabular}

Table 3

\section{TGF-ß semi quantitative score (all patients)}

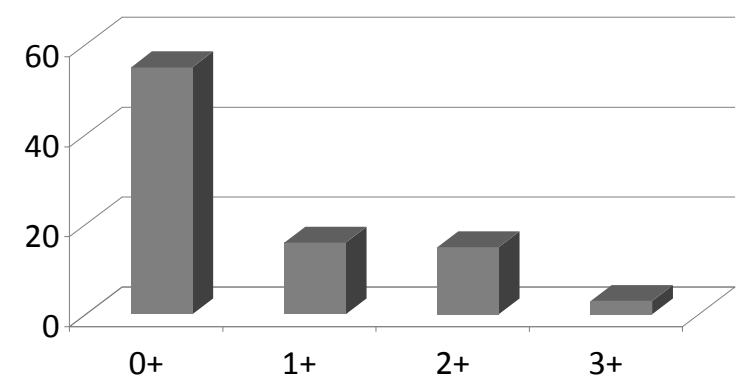

Figure 4-TGF-semiquantitative score

Vimentin - semiquantitative score

\begin{tabular}{lcc}
\hline \multicolumn{2}{l}{ Vimentin - semiquantitative score } & All \\
\hline $0 . \quad 0-10 \%$ positive cells & $4(4.49 \%)$ \\
$1+$. & $11-25 \%$ positive cells & $28(31.46 \%)$ \\
$2+$. & $26-50 \%$ positive cells & $27(30.34 \%)$ \\
$3+$. & $51-75 \%$ positive cells & $30(33.71 \%)$ \\
Total & $89(100 \%)$ \\
\hline
\end{tabular}

\section{Vimentin semiquantitative score (all patients)}

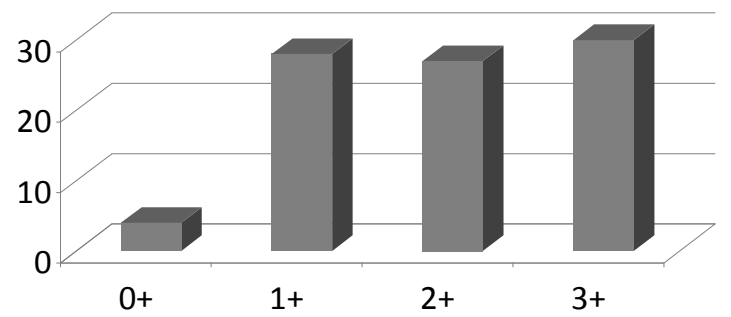

Figure 5 -Vimentin - semiquantitative score 
The semiquantitative score for TGF $\beta$ (Table 2 and Fig 4) showed that the majority of patients demonstrate score 0 which means that the expression of this marker is less than $10 \%$. The scores $1+$ and $2+$ are equally distributed among the other pts.

As far as Vimentin is concerned, our results demonstrate that only $5 \%$ of all patients have a semiquantitive score 0 , i.e. less than $10 \%$ expression of this marker. The rest of the patients are almost equally distributed in scores 1+, 2+ and 3+. (Table 3, Fig 5).

\section{Discussion}

The observed endothelial changes in the time of the AVF creation are already described by other authors who demonstrate that CKD as a state is responsible for many disturbances in the body. The underlying disease, hypertension, advanced ESRD, diabetes, age and gender could affect the normal vascular response and make some patients more prone to developing preexisting endothelial changes. Our histomorphometric analysis demonstrated a various spectrum of endothelial venous changes which could be responsible for the future fistula failure. The intimal-medial area ratio and average intimal-medial thickness presented on Table 1 showed that the majority of our patients had a predominance of medial hypertrophy in the stenotic lesions. This is confirmed by the vein samples histology, where 51 patients were classified with predominant medial hypertrophy and only 19 with intimal hyperplasia. This is opposite to reports by Wasse and Roy-Chaudhury, where the intimal hyperplasia was a dominant pathohistological finding $[7,10]$. Our experience of 89 patients included in the study, which is one of the largest group of patients reported in the literature, is much more representative comparing to the above mentioned studies. It could be one of the explanations of the different results obtained. Finally, the result of the maximal to average intimal-medial thickness ratio express that the neointimal stenotic lesions are eccentric ( Fig. 1).

Regarding the immunohistochemistry, we demonstrate that the marker TGF- $\beta$ is found in less than $40 \%$ of the patients (16 with score $1+$,
15 with score $2+$ and only 3 with score $3+$ ). TGF $\beta$ correlates with local inflammatory processes and oxidative stress. In some amount, both are already confirmed in advanced CKD patients. The TGF $\beta$ positive cells are found in both, intimal hyperplasia and medial hypertrophy. It has been hypothesized that it is created locally from smooth muscle cells (SMC), macrophages and lymphocytes [11, 12]. It is also known that it could be connected with the neointimal cells and it leads to excessive and irreversible deposition of extracellular matrix.

The second marker analyzed using immunohistochemistry is Vimentin as a marker for myofibroblasts and fibroblasts. Regarding Table 3 and Fig 5 we found presence of $\mathrm{Vi}$ mentin positive cells practically in more than $95 \%$ of the patients. It confirms the miofibroblasts' and fibroblasts' activity in advanced ESRD in both, intima and media. The high prevalence of Vimentin in media and intima suggests that phenotyping switching from myofibroblast to fibroblast and vice versa is an active process which takes place both in intima and media. It is still not very clear how do myofibroblasts migrate into intima. There are reports which say that they originate from the adventia, media, or even from bone marrow as a progenitor cells which transform locally into myofibroblasts or SMC or fibroblasts [13-16]. Finally, it means that the fibrosis is also involved in the endothelial damage.

We did not find any positive staining for KI67, which means that we could not find evidence for cellular proliferation. Maybe, the reason is that as we did a single measurement we missed the time when the cell proliferation occurs.

In conclusion, we believe that the endothelial damage in advanced ESRD could play some role in future fistula failure. We demonstrate that the medial hypertrophy is predominant preexisting pathohistological lesion, despite the presence of neointimal hyperplasia in our group of patients. The absence of TGF $\beta$ expression in the majority of our patients could suggest that inflammation and the oxidative stress are developing later, after vascular access surgery. The increased presence of myofibro- 
blasts and fibroblasts (Vimentin positive cells) in media and intima is a reason why some patients could be prone to the developing venous endothelial changes as a results of exaggerated vascular endothelial response to the effect of uremia, hypertension and other insults.

\section{REFERENCES}

1. Roy-Chaudhury P, Sukhatme VP, Cheung AK. Hemodialysis vascular access dysfunction: a cellular andmolecular view point. J Am Soc Nephrol. 2006; 17: 1112-1127.

2. Lee T,Roy-Chaudhury P.Advances and new frontiers in the pathophysiology of venous neointimal hyperplasia and dialysis access stenosis. Adv Chronic Kidney Dis. 2009; 16: 329-338.

3. Oncevski A, Dejanov P, et al: Vascular access and chronic renal failure. ANN UROL, 34(5), 2000; pp. 345-351.

4. Dember LM, Beck GJ, Allon M, et al. Effect of clopidogrel on early failure of arteriovenous fistulas for hemodialysis. JAMA. 2008; 299: 2164-2171. [PubMed: 18477783]

5. Ernandez T, Saudan P, Berney T, et al. Risk factors for early failure of native arteriovenous fistulas. Nephron Clin Pract. 2005; 101: c39-c44.

6. Monroy-Cuadros M, Yilmaz S, Salazar-Banuelos A, et al. Risk factors associated with patency loss of hemodialysis vascular access within 6 months. Clin J Am Soc Nephrol. 2010; 5: 1787-1792.

7. Wasse H, Huang R, Naqvi N, Smith E, Wang D, Husain A Inflammation, oxidation and venous neointimal hyperplasia precede vascular injury from AVF creation in CKD patients. J Vasc Access. 2012 AprJun; 13(2): 168-74.

8. Lee T., Novel paradigms for dialysis vascular access: downstream vascular biology - is there a final common pathway? Clin J Am Soc Nephrol. 2013; 8: 2194-2201.

9. Duque JC, Vazquez-Padron RI. Myofibroblasts: the ideal target to prevent arteriovenous fistula failure? Kidney Int. 2014 Feb; 85(2): 234-6.

10. Roy- Chaudhury P, Arend L, Zhang J et al. Neointimal Hyperplasia in Early Arteriovenous Fistula Failure. Am J Kidney Disease. 2007; 50: 782-770.

11. Tellides G, Tereb DA, Kirkiles-Smith NC, et al: Interferon-Gamma elicits arteriosclerosis in the absence of leukocytes. Nature. 403: 207-211, 2000.

12. Porreca E, Di Febbo C, Mincione G, et al: Increased TGF- $\beta$ production and gene expression by peripheral blood monocytes of hypertensive patients. Hypertens. 1997; 30: 134-139.

13. Shi Y, O'Brien JE Jr, Mannion JD, et al.. Remodeling of autologous saphenous vein grafts. The role of perivascular myofibroblast. Circulation. 1997; 95: 2684-2693.

14. Shi Y, Pieniek M, Fard A, et al. Adventitial remodeling after coronary arterial injury. Circulation. 1996; 93: 340-348.

15. Sata MYH, Nagai R. Circulating recipient cells contribute to graft coronary arteriolosclerosis. J Cardiol. 2002; 39: 48-49.

16. Owens GK. Regulation of differentiation of vascular smooth muscle cells. Physiol Rev. 1995; 75: 487-517.

Резиме

ЗНАЧАЈНО ЕНДОТЕЛНО ОШТЕТУВАЊЕ КАЈ ПАЦИЕНТИТЕ СО ХРОНИЧНА БУБРЕЖНА БОЛЕСТ ПРЕД КРЕИРАЊЕ НА ВАСКУЛАРНИОТ ПРИСТАП

\section{Владимир Пушевски ${ }^{1}$, Петар Дејанов ${ }^{1}$, Весна Герасимовска ${ }^{1}$, Гордана Петрушевска ${ }^{2}$, Ангел Ончевски ${ }^{3}$, Александар Шиколе', Живко Попов ${ }^{4}$, Нинослав Ивановски ${ }^{1}$}

${ }^{1}$ Универзитетска клиника за нефрологија, Скопје, Р. Македонија

${ }^{2}$ Институт за патологија, Скопје, Р. Македонија

${ }^{3}$ Универзитет „Св Кирил и Методиј“, Скопје, Р. Македонија

${ }^{4}$ Македонска академија на науките и уметностите, Скопје, Р. Македонија

Boвeg: Хемодијализата претставува најефикасен третман за лекување на хроничната бубрежна болест (ХББ) во напреден стадиум. Иако примарната артериовенска фистула (АВФ) се смета како најдобар траен васкуларен пристап кај пациентите на хемодијализа, до $60 \%$ од сите фистули рано откажуваат. Патогенезата на раното откажување на АВФ не е доволно објаснета. Бројни општи и локални фактори се вклучени: возраста на пациентот, пол, примарната бубрежна болест, малиот дијаметар на крвните садови, присуство на акцесорни вени, претходни боцкања на вените, хируршко искуство, генетика итн. Хистолошите испитувања ја потврдија неоинтималната венска хиперплазија како главен патолошки наод во стенотичните лезии кај откажаните АВФ, поради локална инфламација, 
оксидативен стрес и миграција и пролиферација на миофибробласти, фибробласти и ендотелни клетки.

Майеријал и мейоgи: Вкупно 89 пациенти со ХББ ст. 4 и 5 беа вклучени во оваа студија. Типична радиоцефалична АВФ беше креирана кај сите пациенти. Дел од фистулната вена беше земен за хистолошка, имунохистохемиска (виментин, ТГФ-бета и КИ 67) и морфометриска анализа.

Резулйайи: Речиси кај $80 \%$ од пациентите беше најден одреден степен на ендотелни промени во моментот на креирање на АВФ, и тоа 19 пациенти со значајна интимална хиперплазија, 51 со медијална хипертрофија, а 19 пациенти имаа нормална хистологија. Кај приближно две третини од пациентите не беше најдена експресија на ТГФ-бета, додека кај повеќе од 95\% од пациентите постоеше одреден степен на експресија на виментин. Кај ниеден пациент не беше најдена експресија на маркерот КИ 67.

Заклучок: Медијалната хиперплазија претставува предоминантна патохистолошка лезија пред креирање на АВФ и покрај присуството на неоинтималната хиперплазија. Отсуството на експресијата на ТГФ-бета кај повеќето пациенти сугерира дека инфламацијата и оксидативниот стрес се јавуваат подоцна, по креирање на васкуларниот пристап. Доминантни клетки во стенотичната лезија се миофибробластите. Нивното зголемено присуство можеби е причина зошто некои пациенти се склони кон развивање венски ендотелни промени како резултат на претеран ендотелен васкуларен одговор на ефектите на уремија, хипертензија и други инсулти.

Клучни зборови: откажување на фистули, ХББ, интимална хиперплазија, виментин, ТГФ-бета 